\title{
Asymmetric synthesis of propargylamines as amino acid surrogates in peptidomimetics
}

\author{
Matthias Wünsch, David Schröder, Tanja Fröhr, Lisa Teichmann, Sebastian Hedwig, \\ Nils Janson, Clara Belu, Jasmin Simon, Shari Heidemeyer, Philipp Holtkamp, \\ Jens Rudlof, Lennard Klemme, Alessa Hinzmann, Beate Neumann, \\ Hans-Georg Stammler and Norbert Sewald ${ }^{*}$
}

\author{
Full Research Paper \\ Address: \\ Organic and Bioorganic Chemistry, Department of Chemistry, \\ Bielefeld University, Universitätsstraße 25, D-33615 Bielefeld, \\ Germany \\ Email: \\ Norbert Sewald - norbert.sewald@uni-bielefeld.de \\ * Corresponding author \\ Keywords: \\ amino acid analogous side chains; desilylation; Ellman's chiral \\ sulfinamide; intramolecular Huisgen reaction; peptidomimetics; \\ propargylamines; rearrangement to $\alpha, \beta$-unsaturated imines
}

Beilstein J. Org. Chem. 2017, 13, 2428-2441. doi:10.3762/bjoc. 13.240

Received: 08 August 2017

Accepted: 19 October 2017

Published: 15 November 2017

Associate Editor: S. Flitsch

(c) 2017 Wünsch et al.; licensee Beilstein-Institut.

License and terms: see end of document.

\begin{abstract}
The amide moiety of peptides can be replaced for example by a triazole moiety, which is considered to be bioisosteric. Therefore, the carbonyl moiety of an amino acid has to be replaced by an alkyne in order to provide a precursor of such peptidomimetics. As most amino acids have a chiral center at $\mathrm{C}^{\alpha}$, such amide bond surrogates need a chiral moiety. Here the asymmetric synthesis of a set of $24 \mathrm{~N}$-sulfinyl propargylamines is presented. The condensation of various aldehydes with Ellman's chiral sulfinamide provides chiral $N$-sulfinylimines, which were reacted with (trimethylsilyl)ethynyllithium to afford diastereomerically pure $N$-sulfinyl propargylamines. Diverse functional groups present in the propargylic position resemble the side chain present at the $\mathrm{C}^{\alpha}$ of amino acids. Whereas propargylamines with (cyclo)alkyl substituents can be prepared in a direct manner, residues with polar functional groups require suitable protective groups. The presence of particular functional groups in the side chain in some cases leads to remarkable side reactions of the alkyne moiety. Thus, electron-withdrawing substituents in the $\mathrm{C}^{\alpha}$-position facilitate a base induced rearrangement to $\alpha, \beta$-unsaturated imines, while azide-substituted propargylamines form triazoles under surprisingly mild conditions. A panel of propargylamines bearing fluoro or chloro substituents, polar functional groups, or basic and acidic functional groups is accessible for the use as precursors of peptidomimetics.
\end{abstract}

\section{Introduction}

Terminal alkynes display an intriguing versatility as building blocks in organic and medicinal chemistry, as their reactivity is unique. Their chemistry involves several highly selective reac- tions, e.g., $[3+2]$ cycloadditions with azides and isoelectronic functional groups (among them the copper or ruthenium-catalyzed azide-alkyne cycloaddition, CuAAC and RuAAC), the 
thiol-yne reaction, Diels-Alder reactions and the Sonogashira cross-coupling. While amino acids with a terminal alkyne in the side chain are well-known, the synthesis of their correlates where the carboxy group is replaced by a terminal alkyne is still tedious. Nevertheless, these propargylamines have been frequently used as precursors for the synthesis of diverse bioactive compounds. Their conversion into triazoles is best investigated, since triazoles as amide bond surrogates are found in several inhibitors of proteases such as cathepsin S [1-6], cysteine proteases [7], cruzain 20 [8,9], caspases [10] and peptidyl aminopeptidases [11]. These protease inhibitors show potential for the treatment of Chagas disease [2,9], Huntington's disease [10], malaria [11], autoimmune diseases [6] and the imaging of tumor associated macrophages [2]. Whereas the carboxylic acid function of amino acids can be easily converted into amides or esters (Figure 1), propargylamines have been converted into acids, alcohols [12] or olefins in order to obtain natural products like angustureine and cuspareine [13].

Intramolecular Pauson-Khand reaction [14], Diels-Alder reaction [15], gold-catalyzed azetidin-3-one formation [16], as well as various transition metal-mediated additions and cross-coupling reactions [17] represent further important reactions of propargylamines, providing the potential to form innovative peptidomimetics (Figure 2).

Our attention has been focused on the synthesis of amino acid analogous propargylamines, furnished with $\mathrm{C}^{\alpha}$-substituents imitating various amino acid side chains.

The direct conversion of amino acids into propargylamines by the Corey-Fuchs or the Seyferth-Gilbert homologation has

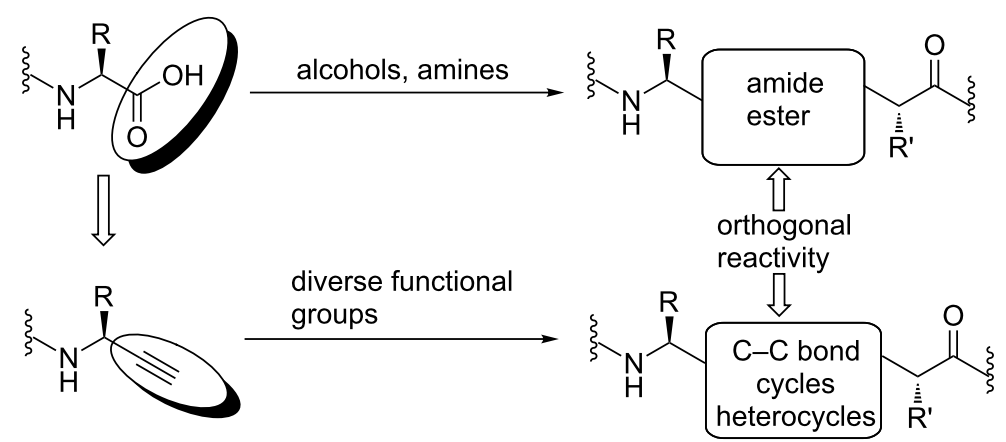

Figure 1: Concept of carboxylic acid or amide bond replacement on the basis of an alkyne moiety.

a)<smiles>[R]C1C2=CCC[C@H]2[C@H]([R])N1[R]</smiles>

b)<smiles>[R]NC([R])C1=CCC([R7])=CC1</smiles>

c)<smiles>[R][C@@H]1C(=O)CN1CCCCCCCC</smiles>

$\mathrm{R}^{\prime}$
Pauson-Khand

reaction

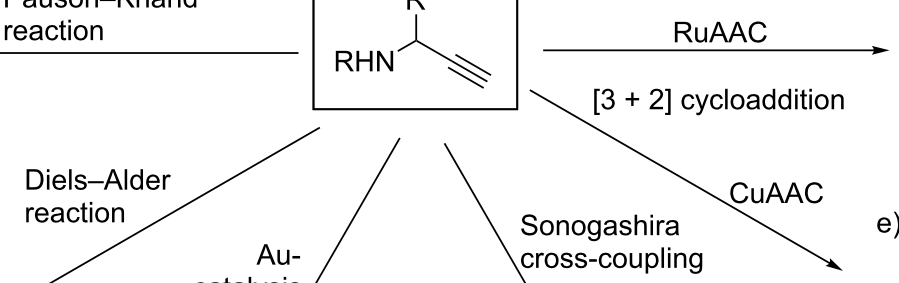

d) cross-coupling<smiles>[R]NC([R])c1cnnn1C([R])C(C)=O</smiles>

e)<smiles>[R]NC([R])C#Cc1ccc(C(C)=O)cc1</smiles>

Figure 2: Selection of reactions based on propargylamines as precursors. a) Intramolecular Pauson-Khand reaction, $R=(S)$-tert-butylsulfinyl, $\mathrm{R}^{\prime}=\mathrm{CH}_{2} \mathrm{CH}_{2} \mathrm{OTBDPS}$ [14]. b) Diels-Alder reaction, $\mathrm{R}=p T s, \mathrm{R}^{\prime}=\mathrm{H}, \mathrm{R}^{\prime \prime}=\mathrm{Me}$ [15]. c) Gold-catalyzed intramolecular reaction to azetidin-3-ones, $\mathrm{R}=$ tert-butylsulfonyl, $\mathrm{R}^{\prime}=$ aromatics, aliphatics [16]. d) Sonogashira cross-coupling, $\mathrm{R}=$ tert-butylsulfinyl, $\mathrm{R}^{\prime}=\mathrm{Me}, \mathrm{CHMe}_{2}, \mathrm{CH}_{2} \mathrm{CHMe}_{2}, \mathrm{cyclohexyl}$

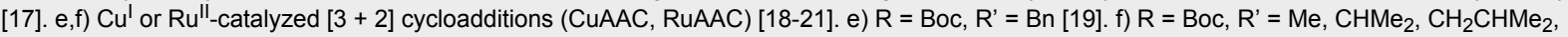
$\mathrm{R}^{\prime \prime}=\mathrm{Me}, \mathrm{CHMe}_{2}, \mathrm{CH}_{2} \mathrm{Ph}[21]$. 
been successfully used for the preparation of several natural amino acid analogues [22,23]. However, epimerization in the $\alpha$-position frequently occurs under the alkaline reaction conditions of the Seyferth-Gilbert and the Corey-Fuchs reaction. In order to access propargylamines with modified side chains, we chose a de novo synthesis strategy, using Ellman's chiral sulfinamide auxiliary to produce diastereomerically pure amines [7]. Ellman's chiral sulfinamide can be readily synthesized on a laboratory scale [24]. Moreover, sulfinamides can be cleaved easily under acidic conditions $[1,25,26]$ and the produced sulfinic acid can even be recycled $[25,27]$. However, the sulfinamide auxiliary has to be treated with care, as it tends to disproportionate quickly in solution at elevated temperature or in chloroform at room temperature [28]. Furthermore, sulfinamides are unstable upon sonication [28]. Sulfinamides are also reported to decompose in the presence of low concentrations of acid under pressure, typical conditions of HPLC analysis. Consequently, the application of the tert-butylsulfinyl as protective group for the amine is restricted to very mild conditions. However, it can be easily cleaved from $N$-sulfinyl propargylamines by acidic methanolysis and subsequent Boc protection [21]. Here we report on the diastereoselective synthesis of chiral $N$-sulfinyl propargylamines with amino acid type "side chains" attached to the propargylic position mediated by Ellman's auxiliary.

Enantiomerically pure amines can be obtained by condensation of aldehydes or ketones with Ellman's chiral sulfinamide, mediated by $\mathrm{KHSO}_{4}$ [29], $\mathrm{Cs}_{2} \mathrm{CO}_{3}$ [30], $\mathrm{Ti}(\mathrm{OEt})_{4}$ [31-33], or $\mathrm{CuSO}_{4}$ [34], followed by either reduction [35-40] or addition of a nucleophile to the imine [41]. In general, there are two options (Figure 3 ) for the synthesis of enantiomerically pure propargylamines by nucleophilic addition. The synthesis of propargylamines by diastereoselective reductive amination requires alkynyl ketones, which are difficult to prepare and are unstable towards reductive conditions.

In approach I, organometallic nucleophiles are added to $\mathrm{N}$-sulfinyl propargylimines, derived from aldehydes. According to approach II, a metallated terminal alkyne is added to an $\mathrm{N}$-sulfinylaldimine. In approach I, the organometallic nucleo- phile is transferring the amino acid side chain, in approach II, the amino acid side chain comes from the aldehyde incorporated in the imine.

\section{Results and Discussion Synthesis of propargylamines, general strategies}

To avoid side reactions of the terminal alkyne in approach I, internal alkynes were applied. Benzoate substituents were chosen as they are comparatively inert and convertible to peptidomimetics. At first, iodobenzene derivatives with an ester moiety in $p$ - or $m$-position were reacted with propargyl alcohol in a Sonogashira reaction to give the phenylpropargyl alcohols $\mathbf{1 a}$ and $\mathbf{1 b}$ (Figure 4) $[42,43]$, which were transformed in a Swern oxidation to afford the aldehydes $\mathbf{2 a}$ and $\mathbf{2 b}$ [44]. Condensation of the aldehydes $\mathbf{2} \mathbf{a}$ and $\mathbf{2} \mathbf{b}$ with $(R)$-configured tertbutyl sulfinamide led to the enantiomerically pure sulfinylimines $\mathbf{3} \mathbf{a}$ and $\mathbf{3} \mathbf{b}$, which were reacted with a variety of organometallic compounds, including iPrMgBr, $\mathrm{MeMgBr}$ and $\mathrm{BnMgBr}$.

The reaction of the enantiomerically pure $N$-sulfinylimines $\mathbf{3 a}$ and $\mathbf{3 b}$ with aliphatic organometallic nucleophiles resulted in low yields and diastereoselectivity. The reaction of sulfinylimine 3a with isopropylmagnesium bromide provided the sulfinamide $4 \mathbf{a}$ in only $13 \%$ yield with a ratio of diastereomers of $99: 1$. Only $10 \%$ of the addition product $\mathbf{4 b}$ were obtained by addition of methylmagnesium bromide to the $N$-sulfinylimine 4b (dr 51:49). In order to prepare phenylalanine analogoues, $\mathrm{N}$-sulfinylimines 3a and $\mathbf{3 b}$ were reacted with benzylmagnesium bromide. However, only traces of the desired addition products could be detected by LC-MS analysis of the crude products.

Approach II starts with the condensation of an aldehyde with Ellman's chiral sulfinamide to provide a sulfinylimine [29-34], which was reacted with (trimethylsilyl)ethynyllithium $[1,14,45-$ 48]. The terminal TMS group was cleaved off after the addition reaction $[49,50]$ (Table 1$)$.

Several conditions for the condensation of aldehydes with Ellman's chiral sulfinamide $(S)-\mathbf{1}$ have been described. Cataly- approach I approach II

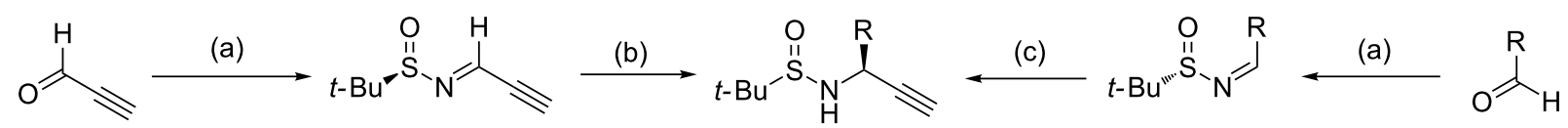




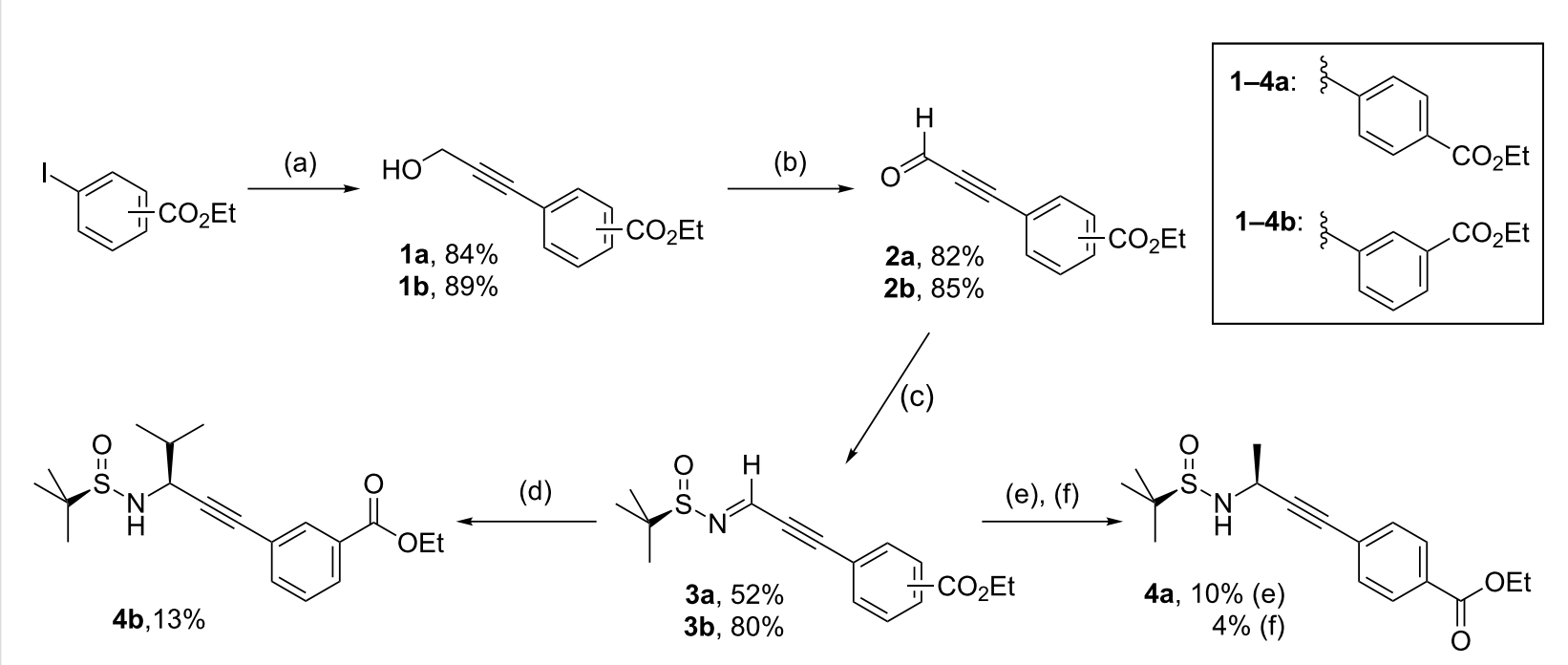

Figure 4: Synthesis of propargylamines $\mathbf{4 a}$ and $\mathbf{4 b}$ by introducing the side chain as nucleophile. (a) $\mathrm{HC} \equiv \mathrm{CCH}_{2} \mathrm{OH}, \mathrm{Cl}_{2} \mathrm{Pd}(\mathrm{PPh})_{2}(1 \mathrm{~mol} \%), \mathrm{Cul}$ (2 mol \%), THF/piperidine (3:1), rt, $2 \mathrm{~h}$. (b) $(\mathrm{COCl})_{2}$, DMSO, $\mathrm{NEt}_{3},-78{ }^{\circ} \mathrm{C}$, DCM. (c) (R)-tert-Butyl sulfinamide $((R)-1)$, CuSO 4 , DCM, rt, $3 \mathrm{~d}$ (see GP-2). (d) iPrMgBr, THF, $-38{ }^{\circ} \mathrm{C}, \mathrm{AlMe}_{3}$ in $n$-hexane (4a, 13\%, dr 99:1). (e) MeLi in $\mathrm{Et}_{2} \mathrm{O}$, toluene, $-30{ }^{\circ} \mathrm{C}, \mathrm{AlMe}_{3}$ in $n$-hexane (4b, $4 \%$, dr $52: 48$ ). (f) $\mathrm{MeMgBr}$ in $\mathrm{Et}_{2} \mathrm{O}$, toluene, $-35^{\circ} \mathrm{C}(\mathbf{4 b}, 10 \%$, dr $51: 49)$.

Table 1: Preparation of $N$-sulfinyl propargylamines 7 with aliphatic side chains. ${ }^{\text {a }}$

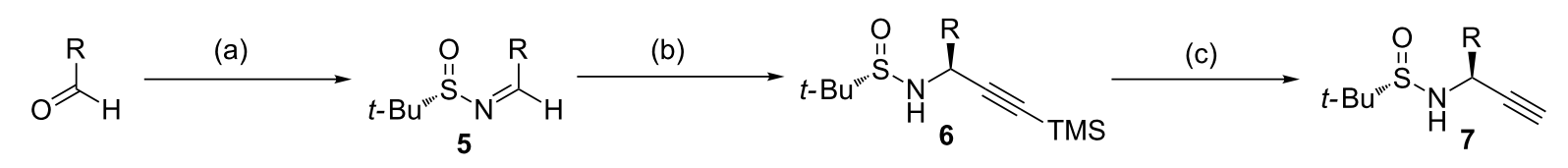

\begin{tabular}{|c|c|c|c|c|c|}
\hline $\mathrm{R}$ & (a) & Yield (5) & (b), (c) & Yield $(7)^{b}$ & $\mathrm{dr}$ \\
\hline $\mathrm{Me}$ & $\mathrm{GP}-1^{\mathrm{C}}$ & $81 \%(5 a)$ & GP-3, GP-5 & $47 \%(7 a)$ & $100: 0$ \\
\hline ¡Pr & GP-1 & $90 \%(5 b)$ & GP-3, GP-5 & $61 \%(7 b)$ & $97: 3$ \\
\hline $\mathrm{CH}_{2}-\mathrm{iPr}$ & GP-1 & $92 \%(5 c)$ & GP-3, GP-5 & $53 \%(7 c)$ & $97: 3$ \\
\hline $\mathrm{C}_{6} \mathrm{H}_{11}$ & GP-2 & $96 \%(5 d)$ & GP-3, GP-5 & $59 \%(7 d)$ & $97: 3$ \\
\hline$t-\mathrm{Bu}$ & GP-2 & $18 \%(5 e)$ & GP-4, GP-5 & $41 \%(7 e)$ & $80: 20$ \\
\hline adamantyl & GP-2 & $42 \%(5 f)$ & GP-4, GP-5 & $15 \%(7 f)$ & $100: 0$ \\
\hline $\mathrm{CH}_{2} \mathrm{CH}_{2} \mathrm{SMe}$ & GP- $2^{c}$ & $89 \%(5 \mathbf{g})$ & GP-4, GP-6 & $34 \%(7 \mathbf{g})^{d}$ & $96: 4$ \\
\hline
\end{tabular}

a(a) GP-1: Auxiliary (S)-1, aldehyde, Ti(OiPr) $4,70^{\circ} \mathrm{C}, 40 \mathrm{~min}$. GP-2: Auxiliary (S)-1, aldehyde, CuSO 4 , DCM, rt, 3 d. (b) GP-3: (Trimethylsilyl)ethynyllithium, $\mathrm{Ti}(\mathrm{OiPr})_{4}, \mathrm{THF},-78^{\circ} \mathrm{C}$ to rt. GP-4: (Trimethylsilyl)ethynyllithium, AlMe 3 , toluene, $-78^{\circ} \mathrm{C}$ to rt. (c) GP-5: TBAF, THF, $0{ }^{\circ} \mathrm{C}, 3 \mathrm{~h}$. GP-6: $\mathrm{KF}$,

18-crown-6, THF/ $\mathrm{H}_{2} \mathrm{O}(98: 2), 0^{\circ} \mathrm{C}$. b ' lsolated yields are given, referring to 5 (over two steps (b) and (c)). ${ }^{\circ} \mathrm{GP}-1$ had to be modified for the synthesis of 5a: acetaldehyde (5 equiv), $\mathrm{MgSO}_{4}\left(5\right.$ equiv), $30^{\circ} \mathrm{C}, 12 \mathrm{~h} \mathrm{[51].}{ }^{\mathrm{d}}(R)$-configured Ellman's sulfinamide $(R)$-1 was applied. Hence, the mirror images of 5-7g were obtained.

sis by Brønstedt acids has been reported [29], but was not considered here due to the lability of the tert-butyl sulfinamide moiety towards acids $[1,25,26]$. Strongly alkaline conditions [30] were also avoided. Liquid aldehydes were readily condensed with tert-butyl sulfinamide $(S)-\mathbf{1}$ in the presence of $\mathrm{Ti}(\mathrm{OEt})_{4}$ as Lewis acid and water scavenger [31-33]. However, the removal of precipitated $\mathrm{TiO}_{2}$ was tedious and time consuming. Therefore, dry $\mathrm{CuSO}_{4}$ as Lewis acid and water scavenger at ambient temperature [34] represented a versatile method, leading to high yields of sulfinylimines $\mathbf{5}$. (Trimethylsilyl)ethynylmagnesium bromide has already been successfully added to sulfinylimines to produce various $N$-sulfinyl propargylamines in excellent yields and diastereomeric excesses $[13,16]$. Several $N$-sulfinyl propargylamines (analogoues of valine, phenylglycine and tyrosine) have been prepared using a large excess (4 equivalents) of [(trimethylsilyl)ethynyl]dimethylaluminum as the nucleophile $[14,48,52]$. The reaction of the sulfinylimines $\mathbf{5}$ with (trimethylsilyl)ethynyllithium provi- 
ded the crude intermediates $\mathbf{6}$, which were converted into the $\mathrm{N}$-sulfinyl propargylamines 7 in high yields and satisfactory diastereomeric ratios by cleaving off the TMS protecting group with TBAF. In previous investigations, the choice of solvent and Lewis acid were controversially discussed [13,14,45-50,5255]. Nonpolar solvents ( $\mathrm{DCM}<\mathrm{THF}<\mathrm{Et}_{2} \mathrm{O}<$ toluene) have been described to enhance the stability of the transition state, improving the diastereomeric ratio, as well as the reactivity of the nucleophile, resulting in an improved yield [45]. As aldimines have been reported to be rather unreactive electrophiles [53], hard Lewis acids $\left(\mathrm{AlMe}_{3}>\mathrm{AlR}_{3}>\mathrm{Ti}(\mathrm{OiPr})_{4}[14]>\right.$ $\mathrm{BF}_{3}>\mathrm{MgBr}_{2}>\mathrm{ZnCl}_{2}>\mathrm{ZnEt}_{2}$ ) have been recommended for activation [45]. However, the Lewis acid $\mathrm{BF}_{3}$ was shown to give products with inverted configuration of the newly formed chiral center [47]. While several authors obtained increased yields upon addition of $\mathrm{AlMe}_{3}[1,45,46]$, others advised against its use as activation agent of aldimines, because side reactions were observed $[13,54,55]$, which will also be further discussed below. We used THF or toluene as solvents and $\mathrm{AlMe}_{3}$ or $\mathrm{Ti}(\mathrm{OiPr})_{4}$ as activation agent. According to Ellman et al., the diastereoselectivity of the addition to sulfinylimines is controlled by the formation of a cyclic, six-membered, chair-like transition state, which is formed by precoordination of the organometallic reagent to aldimine 5 [45]. This cyclic transition state accounts for the preferred $r e$-face attack of the nucleophile at $(S)$-configured $N$-sulfinylimines, which leads to amines with the same configuration as the proteinogenic $(S)$-configured amino acids. This stereoselection was confirmed by various X-ray crystal structures of propargylamines obtained during our investigations like $7 \mathbf{a}, \mathbf{7}-\mathbf{c}, \mathbf{e}, \mathbf{7 s}, \mathbf{7} \mathbf{i}-\mathbf{k}, \mathbf{7 q}$ and triazole 13w (see Supporting Information File 1). Independent on the substituent, solvent and Lewis acid used, the direction of the nucleophilic attack of (trimethylsilyl)ethynyllithium was always the same, forming the new centers of chirality of all $\mathrm{N}$-sulfinyl propargylamines 7 configured as expected. As already described by Ellman et al. [45], the size of the side chain correlates with the result of the reaction. The diastereomeric excesses increased in a size-dependent manner in the order $\mathbf{6 a}$ (alanine) $<$ 6c (leucine) < 6d (cyclohexylglycine) (compare Table 1). The yield of the tert-leucine derivative $6 \mathbf{e}$ was reduced due to sterically shielding of the imino moiety by the tert-butyl group.
The cleavage of the TMS groups of the addition products 6 could be accomplished with TBAF in THF $[49,50,56]$. Basic conditions, like $\mathrm{K}_{2} \mathrm{CO}_{3}$ as described in the literature [50,57] did not lead to the desired $\mathrm{N}$-sulfinyl propargylamines 7 . We assume that strong bases do not only lead to desilylation, but also induce decomposition of the propargylamine system (see below). Kracker et al. recently demonstrated the substitution of the labile tert-butylsulfinyl group of compounds $7 \mathbf{a}-\mathbf{c}$ by the more versatile Boc protective group in yields of 56-94\% [21].

\section{Synthesis of propargylamines containing electron-withdrawing substituents}

Aromatic and carbonyl substituents in the $\mathrm{C}^{\beta}$-position of propargylamines (occurring in analogoues of the amino acids phenylalanine, tyrosine, histidine, tryptophan, aspartic acid and asparagine) increase the acidity of the adjacent protons considerably. In the precursor sulfinylimines 5 of the target propargylamines the acidity of the protons of the methylene moiety is further increased by the electron-withdrawing effect of the adjacent sulfinyl imino moiety. Thus, the nucleophilic addition of (trimethylsilyl)ethynyllithium is competing with deprotonation of the methylene moiety giving rise to the formation of the azaenolate (Figure 5). The resulting anion is reprotonated during aqueous work-up, leading to the starting sulfinylimine $\mathbf{5}$.

Benzyl-substituted $N$-sulfinyl propargylamine $\mathbf{6 h}$ was prepared by the addition of (trimethylsilyl)ethynyllithium to $N$-sulfinylimine $5 \mathbf{h}$. The starting material $\mathbf{5 h}$ and the addition product $\mathbf{6 h}$ were isolated in a 7:3 ratio indicating deprotonation to be the predominant reaction. The phenylalanine analogous $N$-sulfinyl propargylamine $7 \mathrm{~h}$ was isolated in only $12 \%$ yield (over two steps, referring to imine $\mathbf{5 h}$ ) after desilylation with TBAF (Table 2). As the benzylic proton of sulfinylimine $\mathbf{5 h}$ is quite acidic, approach II was not pursued for the synthesis of propargylamines analogous to tyrosine, histidine, tryptophan, and aspartate.

Proteinogenic amino acids do not contain substituents, which additionally increase the acidity of the $\alpha$-proton. Nevertheless, glycine derivatives with electron-withdrawing substituents like

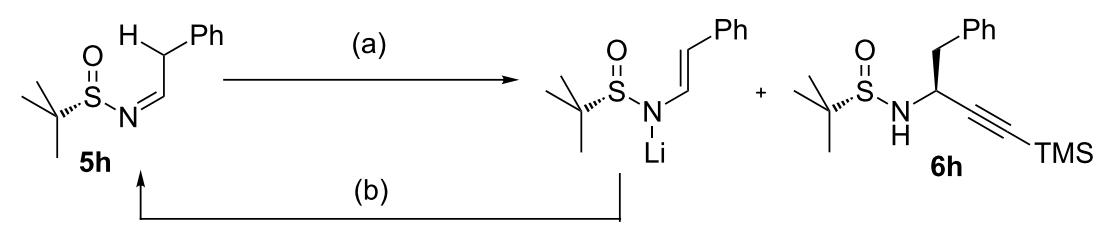

Figure 5: Reaction of $\mathrm{N}$-sulfinylimine $\mathbf{5 h}$ with (trimethylsilyl)ethynyllithium. (a) GP-3 or GP-4. (b) Aqueous work-up, $\mathrm{H}_{2} \mathrm{O} / \mathrm{H}^{+}$. Deprotonation in benzylic position competes with nucleophilic attack $(5 \mathrm{~h} / 6 \mathrm{~h}, 7: 3)$. 
Table 2: Synthesis of propargylamines 7 with electron-withdrawing substituents in the side chain. ${ }^{\text {a }}$

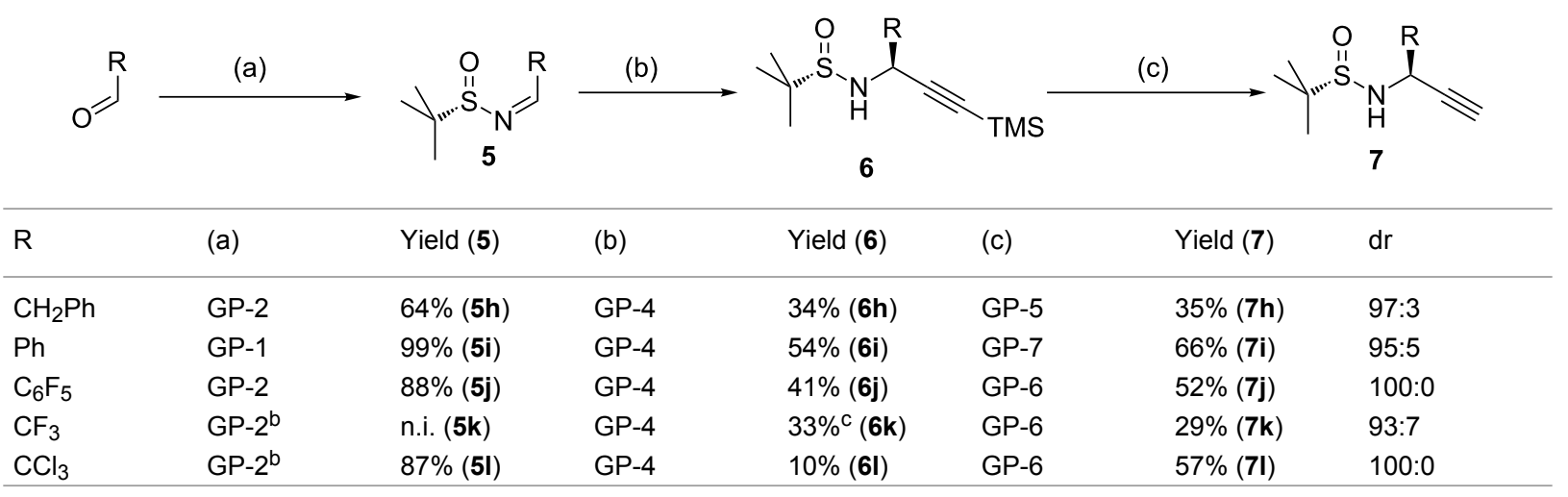

a(a) GP-1: Auxiliary (S)-1, aldehyde, Ti(OiPr) $4,70{ }^{\circ} \mathrm{C}, 40$ min. GP-2: Auxiliary (S)-1, aldehyde, CuSO 4 , DCM, rt, 3 d. (b) GP-4: (Trimethylsilyl)ethynyllithium, $\mathrm{AlMe}_{3}$, toluene, $-78{ }^{\circ} \mathrm{C}$ to rt. (c) GP-5: TBAF, THF, $0{ }^{\circ} \mathrm{C}, 3 \mathrm{~h}$. GP-6: KF, 18-crown-6, THF/H $\mathrm{H}_{2} \mathrm{O}(98: 2), 0{ }^{\circ} \mathrm{C} . \mathrm{GP}-7: 1 . \mathrm{AgNO} 3, \mathrm{EtOH}, 0{ }^{\circ} \mathrm{C}$; 2. $\mathrm{KCN}, \mathrm{EtOH}, \mathrm{HCl}$. ${ }^{\mathrm{b}} \mathrm{For}$ the synthesis of $\mathbf{5 k}$, procedure $\mathrm{GP}-2$ was modified: The aldehyde was distilled under argon atmosphere, condensed onto a mixture of sulfinamide (S)-1 and molecular sieves $4 \AA$. Toluene was added and the solution was stirred for $48 \mathrm{~h}$. $\mathbf{5 k}$ was directly applied for subsequent reactions and could not be isolated (n.i.). 'Yield refers to Ellman's chiral sulfinamide (S)-1.

formylglycine [58,59], phenylglycine [60,61] and fluorinated alanine [62-64] have attracted great attention as peptidomimetics, drugs or in the bioorthogonal functionalization of larger peptides.

The trifluoromethyl moiety has been reported to enhance the activity, stability and selectivity of various pharmacologically active compounds [65,66], e.g., trifluridine [67-70], efavirenz [71-73], fluoxetine [74-76] and fluozolate [77]. As the general structure of fluorinated propargylamines occurs in important drugs, like HIV protease inhibitor DPC 961 and its analogues [78-83], particular effort was put on the synthesis of $N$-sulfinyl propargylamine $7 \mathbf{k}$. Because of the poor electrophilicity of imines $\mathbf{5}$, the nucleophilic addition of trifluoromethyl nucleophiles, such as TMS- $\mathrm{CF}_{3}[84,85]$ has been described to be inefficient. Still, the asymmetric synthesis of $\mathrm{CF}_{3}$-substituted propargylamines has been described, using $(R)$-2-methoxy-1phenylethan-1-amine as chiral auxiliary [86-88]. However, cleavage of the protective group requires reductive conditions, which also affects the $\mathrm{CF}_{3}$ group and the alkyne [86-88].

Various trifluoromethyl-substituted ketones have been converted into $N$-sulfinylimines, which were subsequently transformed into sulfinamides attached to a tertiary $\mathrm{C}$-atom by addition of nucleophiles [89-92]. $\mathrm{N}$-Sulfinyl propargylamine $7 \mathbf{k}$ was prepared, following approach II under varying conditions (Table 2). Fluoral hydrate was dehydrated with concentrated sulfuric acid to give trifluoroacetaldehyde by distillation [93]

The reaction of trifluoroacetaldehyde with tert-butyl sulfinamide $(S)-\mathbf{1}$ in the presence of molecular sieves $4 \AA$ provided the sulfinylimine $\mathbf{5 k}$, which could not be isolated due to its extremely high electrophilicity. Instead, immediate hydrolysis occurs upon contact with water forming hemiaminal $8 \mathbf{k}$ (Figure 6), as already observed by Truong et al. [94]. This frequently observed hemiaminal was isolated by column chromatography and recrystallized from EtOAc.

Distillation of imine $5 \mathbf{k}$ has been reported to provide a very low yield (22\% [94]). The reaction of hemiaminal $8 \mathbf{k}$ with (trimethylsilyl)ethynyllithium in the presence of the strong Lewis acid $\mathrm{AlMe}_{3}$ has been proposed by Truong et al. [94], but was reported to give very poor yields and low diastereoselectivity. In contrast to the argumentation of Xiao et al., who strongly recommended hard Lewis acids for the reaction of sulfinylimines with various ethynyllithium reagents [95], the crude imine 5k predominantly reacted with the Lewis acids $\mathrm{Ti}(\mathrm{OiPr})_{4}$ and $\mathrm{AlMe}_{3}$ and gave only low yields of the desired $N$-sulfinyl propargylamine $6 \mathbf{k}$. The reaction of crude $5 \mathbf{k}$ in the presence of the Lewis acid $\mathrm{Ti}(\mathrm{OiPr})_{4}$ afforded the N/O-acetal 9k, whereas the attempt of activation with $\mathrm{AlMe}_{3}$ provided the methylated sulfinamide 10k. Both side products were isolated as colorless crystalline solids. It is assumed, that the undesired side products $9 \mathbf{k}$ and $10 \mathbf{k}$ were formed by a ligand transfer from the Lewis acids to imine $\mathbf{5 k}$. Nucleophilic substitution of N/Oacetal 9k with two equivalents of (trimethylsilyl)ethynyllithium, in analogy to the conversions reported by Kuduk et al. [96], remained unsuccessful. The $(S)$-configuration of the newly generated chiral center of amine 10k was determined by X-ray structure analysis (Figure 7), suggesting two possible transition states for the ligand transfer.

Whereas transition state TII requires only one equivalent of $\mathrm{AlMe}_{3}$, two equivalents of $\mathrm{AlMe}_{3}$ are involved in transition 


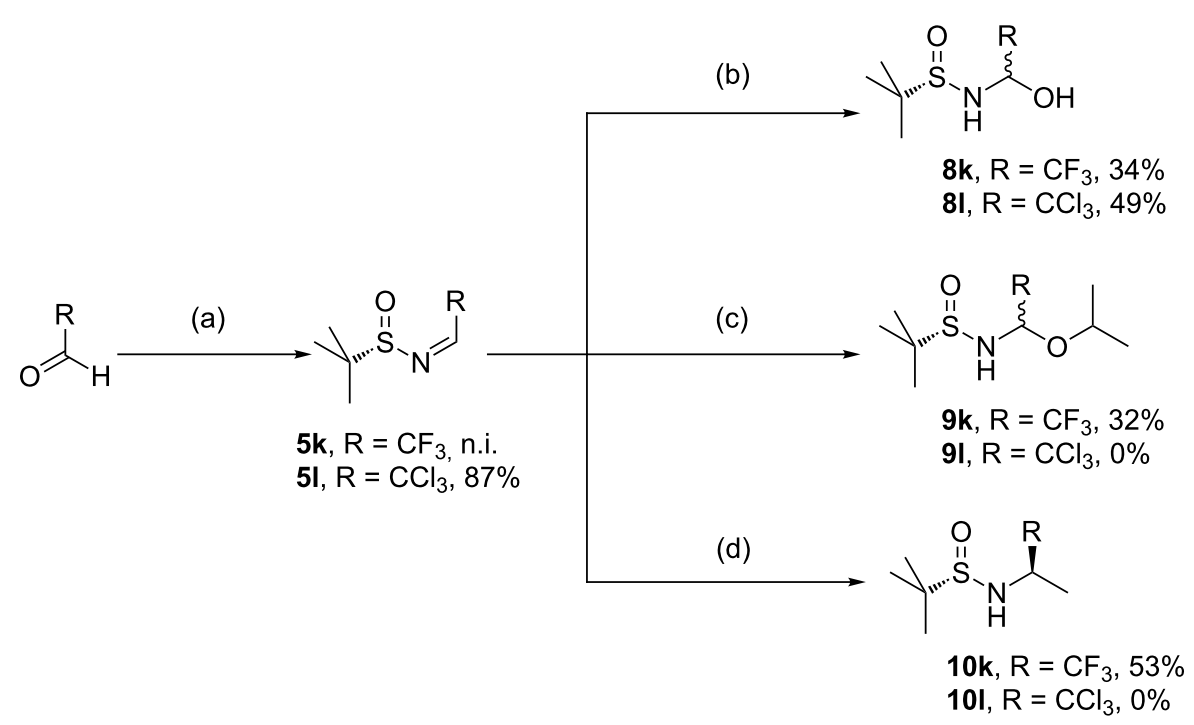

Figure 6: Side reactions observed in the course of the conversion of highly electrophilic sulfinylimines 5. (a) Sulfinamide (S)-1, molecular sieves $4 \AA$, toluene. (b) 1. Dilution with $\mathrm{H}_{2} \mathrm{O}$, 2. Extraction with DCM. (c) Addition of Ti(OiPr) 4 prior to the conversion with (trimethylslyl)ethynyllithium [94]. (d) Addition of $\mathrm{AlMe}_{3}$ prior to the conversion with (trimethylsilyl)ethynyllithium.

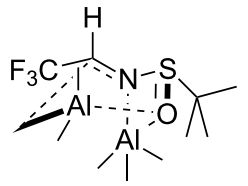

TI<smiles>CC1(C)CC(F)=C(F)N2C(C)(C)N1[SH]2(=O)C(C)(C)C</smiles>

TII

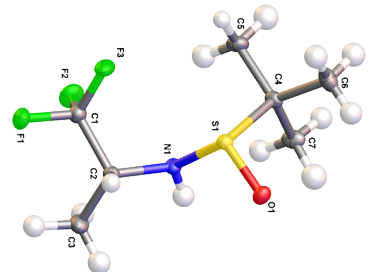

Figure 7: a) Possible transition states TI and TII for the transfer of the methyl moiety from $\mathrm{AlMe}_{3}$ to the imino moiety. b) X-ray crystal structure analysis of the methyl transfer product 10k.

state TI. As in this case almost quantitative conversion of $\mathrm{AlMe}_{3}$ was observed, transition state TII seems to be more probable. Still, more complex coordination geometry (hexagonal or dinuclear complexes) of the Lewis acid are probable as well and hardly depend on the stoichiometry. In the conversion of highly reactive sulfinylimines like $\mathbf{5 k}$, best results were obtained in the absence of a Lewis acid. Analogous investigations with chloral hydrate instead of fluoral hydrate showed that the trichloromethylimine $\mathbf{5 l}$ also forms a hemiaminal $\mathbf{8 1}$ upon contact with water, but does not undergo comparable side reactions with $\mathrm{Ti}(\mathrm{OiPr})_{4}$ or $\mathrm{AlMe}_{3}$. Sulfinylimine $\mathbf{5 l}$ appears to be a weaker electrophile, which is attributed to the lower electronegativity of $\mathrm{Cl}$ compared to $\mathrm{F}$ and to the larger size of the $\mathrm{CCl}_{3}$ group compared to the $\mathrm{CF}_{3}$ moiety, sterically shielding imine $\mathbf{5}$ against nucleophilic attack.

Desilylation of $N$-sulfinyl propargylamine $6 \mathbf{i}$ with TBAF (GP-5) resulted in decomposition instead of formation of the free alkyne 7i. In order to obtain the free terminal alkyne $\mathbf{7} \mathbf{i}$, a milder desilylation procedure was required. Therefore, $\mathrm{AgNO}_{3}$ and $\mathrm{KCN}$ (GP-7) were used for the desilylation of $\mathbf{6 i}$ to afford the free alkyne $7 \mathbf{i}$ in $66 \%$ yield. $N$-Sulfinyl propargylamines $6 \mathbf{k}$ and $\mathbf{6 j}$, with perfluorinated side chains, required even milder desilylation conditions. KF in the presence of 18-crown-6 (GP-6) provided the free alkynes $7 \mathbf{k}$ and $7 \mathbf{j}$ in $29 \%$ and $52 \%$ yield, respectively (results are collected in Table 2).

Desilylation of alkynes $\mathbf{6 k}$ and $\mathbf{6 j}$ under alkaline conditions with $\mathrm{K}_{2} \mathrm{CO}_{3}$, in analogy to the description of Vasella et al. [57] leads to instant decomposition of the starting material in a basepromoted propargyl-allenamide isomerization. According to our hypothesis, basic fluoride leads to deprotonation in the $\mathrm{C}^{\alpha}$-position of $\mathbf{6} \mathbf{i}, \mathbf{6} \mathbf{k}$ and $\mathbf{6 j}$, inducing an alkyne rearrangement to form an allene, which rearranges further to provide an $\alpha, \beta$ unsaturated imine (Figure 8) [97].

One target application of propargylamines 7 is the Sonogashira cross-coupling with halogenated benzoates, forming the scaf- 


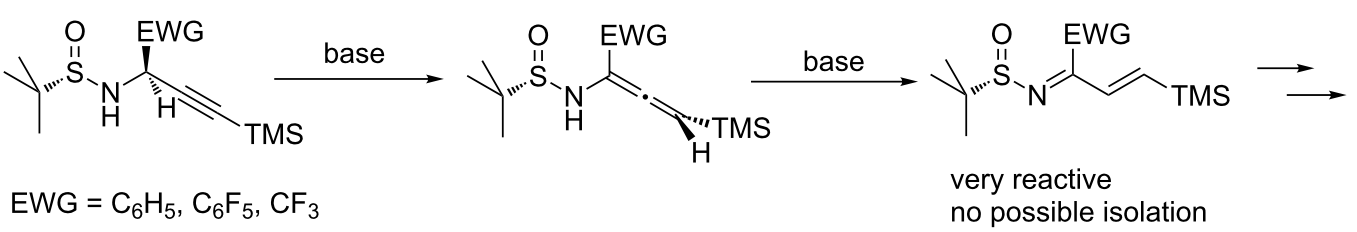

Figure 8: Base-induced rearrangement of propargylamines bearing electron-withdrawing substituents.

fold of versatile peptidomimetics 11. According to the proposed rearrangement of alkyne 7 (Figure 9), the choice of base is crucial for such cross-coupling reactions. To get a better understanding of the reactivity of propargylamines, the stability and propensity for base induced rearrangement of $\mathbf{1 1}$ were investigated (Figure 9).
A)<smiles>C#CC(NS(=O)C(C)(C)C)C(C)(C)C</smiles>

$7 \mathrm{k}, \mathrm{EWG}=\mathrm{CF}_{3}$

(a)<smiles>CC(C)(C)S(N)=O</smiles><smiles>CC#CC(NC)NC(C)(C)C</smiles><smiles>C1#CCCCCC1</smiles><smiles>[B]c1ccccc1I</smiles>

11i, $E W G=P h, A=H, B=\mathrm{CO}_{2} \mathrm{Me}, 54 \%$ 11k, EWG $=\mathrm{CF}_{3}, \mathrm{~A}=\mathrm{CO}_{2} \mathrm{Me}, \mathrm{B}=\mathrm{H}, 45 \%$

(b) 7i, EWG $=P h$

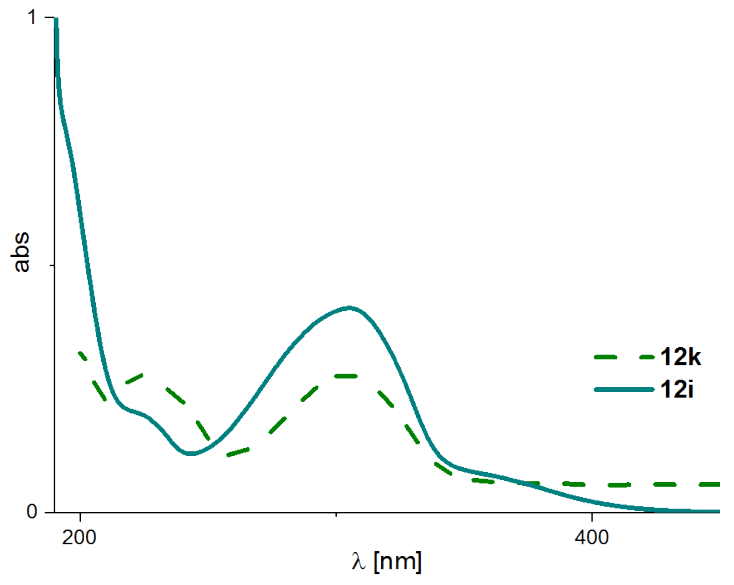

C)

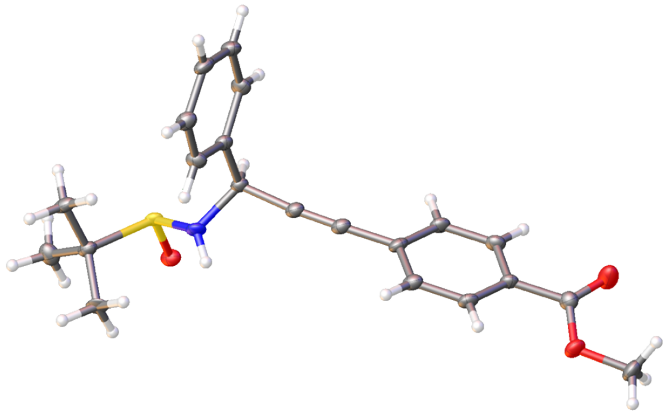<smiles>[Y]c1cc(/C=C/C([Y6])C(C)(C)C)ccc1Br</smiles>

12i, $E W G=P h, A=H, B=\mathrm{CO}_{2} \mathrm{Me}$, $X=$ tert-butyl sulfinyl, $98 \%$ 12k, EWG $=\mathrm{CF}_{3}, \mathrm{~A}=\mathrm{CO}_{2} \mathrm{Me}, \mathrm{B}=\mathrm{H}$, $\mathrm{X}=\mathrm{H} 84 \%$
B)

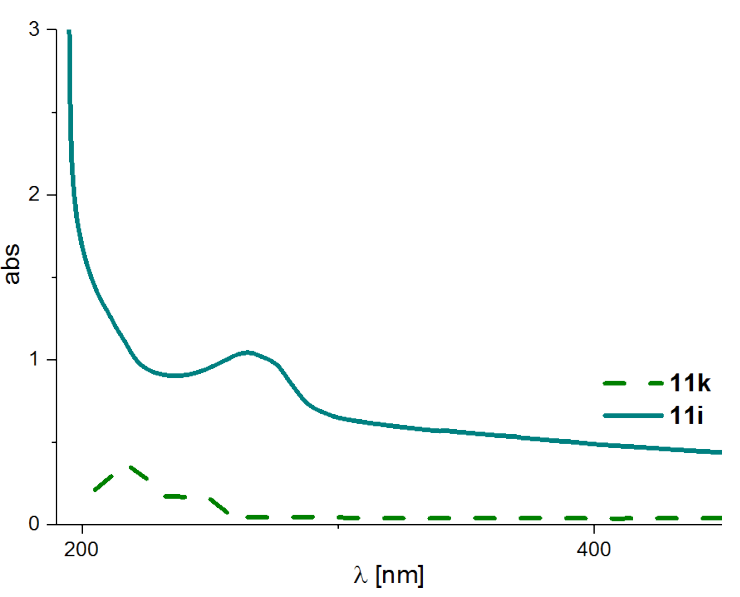

Figure 9: Base-catalyzed rearrangement of propargylamines 11 to $\alpha, \beta$-unsaturated imines 12. A) Reaction scheme: (a) methyl 4-iodobenzoate (for

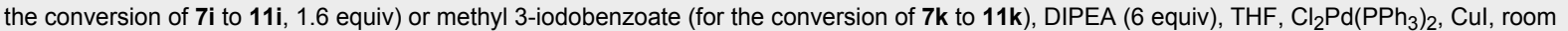
temperature, $2 \mathrm{~h}$ (GP-9). (b) Piperidine/THF (1:3), $0{ }^{\circ} \mathrm{C}, 30 \mathrm{~min}$ (conversion of 11i to 12i). Or LiOH (3 equiv), $\mathrm{MeOH} / \mathrm{H}_{2} \mathrm{O}(2: 1), 0{ }^{\circ} \mathrm{C}, 30 \mathrm{~min}$. B) UV-vis spectra of propargylamines 11 and $\alpha, \beta$-unsaturated imines 12 . C) X-ray crystal structure analysis of propargylamine 11i and $\alpha, \beta$-unsaturated imine $12 \mathbf{i}$ 
The ester substituted compounds $\mathbf{1 1} \mathbf{i}$ and $\mathbf{1 1} \mathbf{k}$ were obtained by Sonogashira cross-coupling of the terminal alkynes $7 \mathbf{i}$ and $7 \mathbf{k}$ with methyl 4- and 3-iodobenzoate, respectively. As the tertbutylsulfinyl group can be cleaved off under mild, acidic conditions $[1,25,26]$, it provides a versatile protective group for the amine during the conversion of the alkyne. Additionally, it's chirality indicates epimerization and, for example in the Pauson-Khand reaction [14], allows the determination of the stereoselectivity of asymmetric conversions by simple ${ }^{1} \mathrm{H}$ NMR experiments. Consequently it was not removed prior to the rearrangement experiments.

Treatment of $11 \mathbf{i}$ and $11 \mathbf{k}$ with the mild base piperidine led to the formation of $\alpha, \beta$-unsaturated sulfinylimines $12 \mathbf{i}$ and $\mathbf{1 2 k}$. The structures of the rearranged products were proven unequivocally by ${ }^{1} \mathrm{H}$ and ${ }^{13} \mathrm{C}$ NMR spectroscopy and X-ray crystal structure analysis.

Due to the extended $\pi$-system of the $\alpha, \beta$-unsaturated imines $\mathbf{1 2} \mathbf{i}$ and $12 \mathbf{k}$, the progress of the propargylamide-allenylamide rearrangement that eventually leads to the formation of the $\alpha, \beta$ unsaturated imines by tautomerism could be easily monitored by UV-vis spectroscopy. The reaction mixture turned brightly yellow when treated with bases like piperidine. The X-ray crystal structures of $\mathbf{1 1} \mathbf{i}$ and $\mathbf{1 2} \mathbf{i}$ confirm unequivocally the structure of the products and thus the postulated two-step rearrangement. Both, the rearrangement of the alkyne to the allene and the subsequent tautomerism to the $\alpha, \beta$-unsaturated imine are not reversible. Reversibility of the rearrangement would be fundamental for racemization of propargylamines, which is consequently improbable. However, even in the presence of strong bases like $\mathrm{KO} t$-Bu or LDA, the propargylamide-allenylamide rearrangement could never be observed for propargylamines without an acidifying $\mathrm{C}^{\alpha}$-substituent.

\section{Synthesis of propargylamines containing polar or acidic functional groups}

The synthesis of propargylamines with polar substituents to mimic polar amino acids such as serine (alcohol), cysteine (thiol) or glutamine (carboxamide) requires special protective groups (Table 3 ).

The cyano moiety was used as precursor of the carboxamide moiety of glutamine, since the cyano group is stable in the presence of nucleophiles and strong bases. The synthesis started with the Kolbe nitrile synthesis of 4-iodobutan-1-ol with $\mathrm{NaCN}$. Performing this transformation in DMSO provided the desired 5-hydroxypentanenitrile and THF in the ratio 5:2 (monitored by ${ }^{1} \mathrm{H}$ NMR spectroscopy, see Supporting Information File 1). Next, 4-cyanobutan-1-ol was oxidized in a Swern oxidation and the resulting aldehyde was condensed with tert-butylsulfinamide $(S)-\mathbf{1}$, according to GP-2. The reaction of sulfinimine $\mathbf{5 q}$ with (trimethylsilyl)ethynyllithium led to sulfinamide $\mathbf{6 q}$. In this case, the Lewis acid $\mathrm{AlMe}_{3}$, which could also react with the cyano moiety, was omitted. Finally, cleavage of the TMS group was achieved under mild conditions with KF and 18-crown-6

Table 3: Preparation of $\mathrm{N}$-sulfinyl propargylamines 7 with polar and acidic functional groups in the side chains. ${ }^{a}$

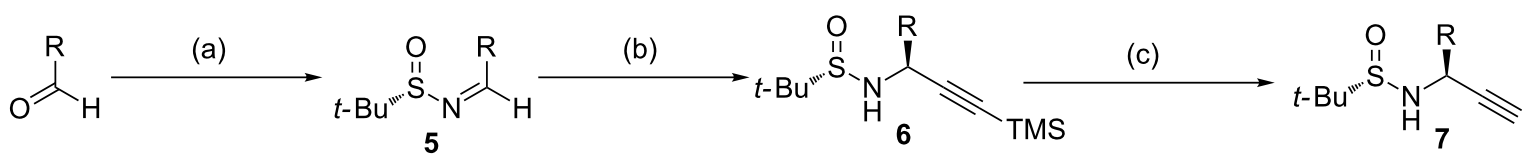

\begin{tabular}{|c|c|c|c|c|c|}
\hline $\mathrm{R}$ & (a) & Yield (5) & (b), (c) & Yield $(7)^{b}$ & $\mathrm{dr}$ \\
\hline $\mathrm{CH}_{2} \mathrm{OCPh}_{3}$ & GP-2 & $47 \%(5 m)$ & GP-4, GP-6 & $0 \%(7 m)^{c}$ & n.d. \\
\hline $\mathrm{CH}_{2} \mathrm{OBn}$ & GP-2 & $81 \%(5 n)^{d}$ & GP-3, GP-5 & $4 \%(7 n)^{e}$ & $95 / 5$ \\
\hline $\mathrm{CH}_{2} \mathrm{OAll}$ & GP-1 & $24 \%(50)$ & GP-4, GP-5 & $31 \%(70)$ & $93 / 7$ \\
\hline $\mathrm{CH}_{2} \mathrm{SBn}$ & GP-2 & $83 \%(5 p)^{d}$ & GP-3, GP-5 & $31 \%(7 p)^{f}$ & $93 / 7$ \\
\hline$\left(\mathrm{CH}_{2}\right)_{3} \mathrm{CN}$ & GP-2 & $80 \%(5 q)$ & GP-4, GP-6 & $43 \%(7 q)$ & $95 / 5$ \\
\hline$\left(\mathrm{CH}_{2}\right)_{2} \mathrm{CO}_{2} \mathrm{Bn}$ & GP-2 & $79 \%(5 r)$ & GP-4, GP-5 & $0 \%(7 \mathbf{r})^{\mathrm{c}}$ & n.d. \\
\hline$\left(\mathrm{CH}_{2}\right)_{2} \mathrm{CO}_{2} t-\mathrm{Bu}$ & GP-2 & $64 \%(5 s)$ & GP-4, GP-6 & $47 \%(7 s)$ & $93 / 7$ \\
\hline$\left(\mathrm{CH}_{2}\right)_{3} \mathrm{OX}^{\mathrm{f}}$ & GP-1 & $90 \%(5 t)$ & GP-3, GP-5 & $27 \%(7 t)$ & $93 / 7$ \\
\hline$\left(\mathrm{CH}_{2}\right)_{3} \mathrm{Cl}$ & GP-1 & $85 \%(5 u)$ & GP-4, GP-5 & $0 \%(7 u)^{c}$ & n.d. \\
\hline$\left(\mathrm{CH}_{2}\right)_{4} \mathrm{~N}_{3}$ & GP-2 & $52 \%(5 v)$ & $f$ & & \\
\hline$\left(\mathrm{CH}_{2}\right)_{3} \mathrm{~N}_{3}$ & GP-2 & $84 \%(5 w)$ & $f$ & & \\
\hline
\end{tabular}

a(a) GP-1: Auxiliary (S)-1, aldehyde, Ti(OiPr) $)_{4}, 70^{\circ} \mathrm{C}, 40$ min. GP-2: Auxiliary (S)-1, aldehyde, $\mathrm{CuSO}_{4}$, DCM, rt, 3 d. (b) GP-4: (Trimethylsilyl)ethynyllithium, $\mathrm{AlMe}_{3}$, toluene, $-78{ }^{\circ} \mathrm{C}$ to rt. (c) GP-5: TBAF, THF, $0{ }^{\circ} \mathrm{C}, 3 \mathrm{~h}$. GP-6: KF, 18-crown-6, THF/ $\mathrm{H}_{2} \mathrm{O}(98: 2), 0{ }^{\circ} \mathrm{C}$. bYields of 7 refer to imine 5 (two steps). ${ }^{\circ}$ Compounds $7 \mathrm{~m}, 7 \mathbf{r}$ and $\mathbf{7 u}$ could not be isolated and the diastereoselectivity could not be determined (n.d.). ${ }^{\mathrm{d}} \mathrm{Further}$ reactions in Table 4 . ${ }^{\mathrm{e}}(R)$-Configured Ellman's sulfinamide $(R)-\mathbf{1}$ was applied. Hence, the mirror images of $\mathbf{5}-\mathbf{7 n}, \mathrm{p}$ were obtained. ${ }^{\mathrm{f}} \mathbf{5 t}, \mathrm{X}=\mathrm{TBDMS}$. $7 \mathrm{t}, \mathrm{X}=\mathrm{H}$. 
(GP-6), to yield $N$-sulfinyl propargylamine $7 \mathbf{q}$ as an analogue of the non-proteinogenic amino acid 5-cyano-L-norvaline. Formation of a glutamine analogous side chain by hydrolysis of the nitrile function to an amide remained unsuccessful so far.

Propargylamines with diversely protected alcohol functionalities in the side chain were obtained by approach II. The application of an allyl ether, starting from 2-allyloxyacetaldehyde to form $7 \mathbf{o}$ and a benzoate, starting from formylmethyl benzoate to form $7 \mathbf{n}$ (Table 3) turned out to be most convenient. In contrast to labile TMS ethers, the sterically more demanding tert-butyl dimethylsilyl ether was successfully applied as protective group to obtain the homologated serine analogous propargylamine $7 \mathbf{t}$ similar to the description by Verrier et al. [47,55], starting from TBDMS-protected oxybutanal. Treatment of alkyne $6 \mathbf{t}$ with TBAF leads to simultaneous cleavage of both silyl groups. Although sterically shielding protective groups have proven convenient, the trityl group turned out to be inefficient to generate a serine-analogous propargylamine. Trityl-protected imine 5m immediately decomposed, when treated with (trimethylsilyl)ethynyllithium.

The preparation of glutamic acid-analogous propargylamines failed when the acid functionality was protected as a benzyl ester. Fortunately, the sterically more demanding tert-butyl ester was stable and gave high yields of $7 \mathbf{s}$. The synthesis started from the aldehyde tert-butyl-4-oxobutanoate, which could be easily obtained from succinic anhydride [44,98,99]. Selective cleavage of the tert-butyl group was not yet accomplished without affecting the tert-butyl sulfinamide protection group of the amine.

A cysteine-analogous alkyne could be synthesized starting from benzylmercaptan. Unfortunately, only extremely low yields were achieved and $\mathrm{N}$-sulfinyl propargylamine $\mathbf{7 p}$ is not stable under the conditions, which are necessary to cleave the thioether $[100,101]$.

\section{Synthesis of propargylamines with basic functional groups in the side chain}

Very often, basic amino acids, like lysine or arginine are found in the catalytic center of enzymes. Therefore, propargylamines mimicking these basic amino acids are of particular interest to be incorporated in peptidomimetics. The exchange of basic amino acids has already been performed to develop potent enzyme inhibitors [102-104]. In order to introduce side chains with basic amino moieties into propargylamines, these have to be protected against nucleophiles, bases and deprotonation.

According to the approach of Ye et al., a 3-bromopropyl side chain was used, which was converted to the azide and further transformed into an aminoalkyl group by Staudinger reduction [16]. In order to follow a more convergent approach and to avoid nucleophilic substitution of the halide at a late stage, we decided to start the synthesis with 4-azidobutanal, which was prepared by opening THF with iodine and $\mathrm{NaBH}_{4}$, nucleophilic substitution by sodium azide and Swern oxidation of the alcohol.

4-Azidobutanal was converted with chiral sulfinamide $(S)$-1 into $\mathrm{N}$-sulfinylimine $\mathbf{5} \mathbf{w}$, which was reacted with (trimethylsilyl)ethynyllithium. However, following the usual procedure GP-4 with warming up the reaction mixture to room temperature before quenching with water led to the formation of triazole 13w, which was isolated in $56 \%$ yield (Table 4 ). The target propargylamine 6wx was obtained in only $19 \%$ yield. Cleavage of the TMS group with $\mathrm{KF}$ and 18 -crown- 6 at $0{ }^{\circ} \mathrm{C}$ provided azide $7 \mathbf{w x}$ in only $22 \%$ yield, because triazole $14 \mathbf{w}$ was formed in a side reaction. Compound $7 \mathbf{w x}$ was converted into triazole $\mathbf{1 4} \mathbf{w}$ even upon standing at room temperature in $\mathrm{CDCl}_{3}$ (monitored by ${ }^{1} \mathrm{H}$ NMR spectroscopy, see Supporting Information File 1). Formation of triazoles $13 w$ and $14 w$ was unexpected, because the uncatalyzed Huisgen reaction usually requires higher temperature or activation by electron-withdrawing substituents at the alkyne or electron-donating substituents at the azide, respectively $[105,106]$. As none of these requirements are met in the case of $\mathbf{6 w x}$ and $\mathbf{7 w x}$, it is assumed, that the preorientation of the azide and the alkyne together with the formation of an energetically favored six-membered ring are the driving forces. As hexose scaffolds similar to $13 w$ and $\mathbf{1 4 w}$ have been successfully applied as inhibitors of $\beta$-glucosidases [107] and hexosamidases [108], this intramolecular Huisgen reaction could be exploited to develop novel enzyme inhibitors.

In order to get access to propargylamines with the side chains of lysine, ornithine and arginine, azide $7 \mathbf{w x}$ should be reduced. However, all attempts to reduce the isolated azide $7 \mathbf{w x}$ with $\mathrm{NaBH}_{4}$ or $\mathrm{PPh}_{3}$ failed, due to the competing triazole formation. Therefore, instant reduction of in situ prepared $6 \mathbf{w y}$ was envisaged. The nucleophilic addition of (trimethylsilyl)ethynyllithium to $N$-sulfinylimine $\mathbf{5 w}$ was monitored by analytical HPLC. After complete conversion, $\mathrm{PPh}_{3}$ was added directly to the reaction mixture at $-78{ }^{\circ} \mathrm{C}$. After addition of water and stirring for two hours, the primary amine $7 \mathbf{w y}$ was isolated in $86 \%$ yield. This procedure led to the ornithine analogous propargylamine $\mathbf{7 w y}$, which was reacted with Boc-protected $S$-methylisothiourea to yield the arginine analogous propargylamine $7 \mathbf{x}$ in a yield of $79 \%$. During the decomposition of the azide in the Staudinger reaction, the TMS group at the alkyne was cleaved off simultaneously. Cleavage of TMS groups with $\mathrm{PPh}_{3}$ under similar conditions has not been reported so far. Therefore, an intramolecular mechanism is postulated, in which 
Table 4: Synthesis of lysine, ornithine and arginine-analogous propargylamines $7 \mathbf{v y}, \mathbf{7 w y}$ and $\mathbf{7 x}$ and discovery of an unexpected intramolecular lowtemperature Huisgen reaction.

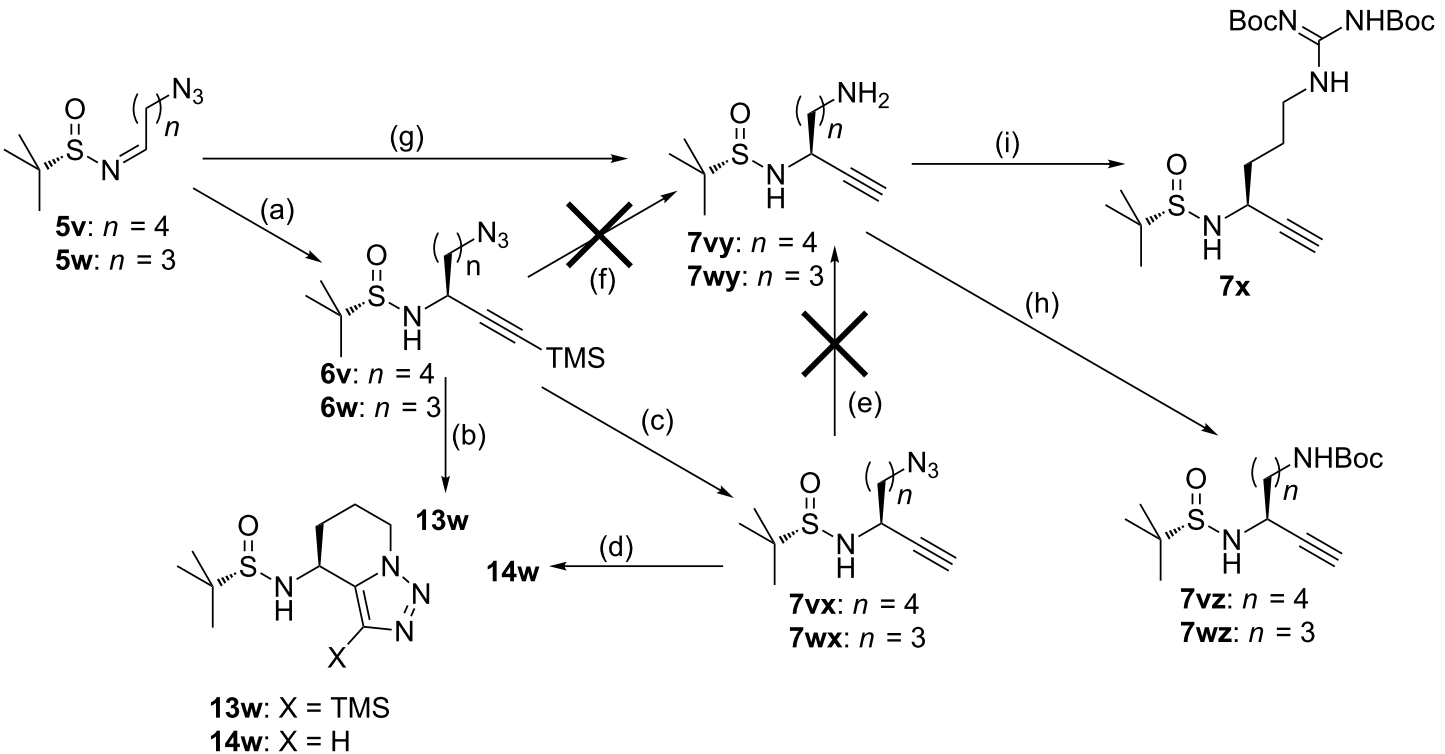

\begin{tabular}{|c|c|c|c|c|}
\hline $\begin{array}{l}\text { Starting } \\
\text { material }\end{array}$ & Reaction conditions & Product & Yield & $\mathrm{dr}$ \\
\hline $5 v$ & (a) (trimethylsilyl)ethynyllithium, $\mathrm{Ti}(\mathrm{OiPr})_{4}, \mathrm{THF},-78^{\circ} \mathrm{C}(\mathrm{GP}-3)$ & $6 v$ & $58 \%$ & $100: 0$ \\
\hline $5 w$ & (a) (trimethylsilyl)ethynyllithium, $\mathrm{Ti}(\mathrm{OiPr})_{4}, \mathrm{THF},-78^{\circ} \mathrm{C} .(\mathrm{GP}-3)$ & $6 w$ & $14 \%$ & n.d. \\
\hline $6 v$ & (b) (trimethylsilyl)ethynyllithium, $\mathrm{AlMe}_{3}$, toluene, $-78^{\circ} \mathrm{C}(\mathrm{GP}-4)$ & $13 w$ & $56 \%$ & $100: 0$ \\
\hline $6 v$ & (c) TBAF (2 equiv), THF, $0{ }^{\circ} \mathrm{C}, 4 \mathrm{~h}(\mathrm{GP}-5)$ & $7 v x$ & $58 \%$ & $74: 26$ \\
\hline $6 w$ & (c) TBAF (2 equiv), THF, $0^{\circ} \mathrm{C}, 4 \mathrm{~h}(\mathrm{GP}-5)$ & $7 w x$ & $19 \%$ & $96: 4$ \\
\hline $7 w x$ & (d) $\mathrm{CDCl}_{3}, 7 \mathrm{~d}$, rt. & $14 w$ & $66 \%$ & $96: 4$ \\
\hline $7 v x$ & (e) 1. $\mathrm{PPh}_{3}, \mathrm{CuSO}_{4}, \mathrm{THF} ; 2 . \mathrm{H}_{2} \mathrm{O}$. & 7vy & $0 \%$ & n.d. \\
\hline $7 w x$ & (e) 1. $\mathrm{PPh}_{3}, \mathrm{CuSO}_{4}, \mathrm{THF} ; 2 . \mathrm{H}_{2} \mathrm{O}$. & $7 w y$ & $0 \%$ & n.d. \\
\hline $6 v$ & (f) $1 . \mathrm{NaBH}_{4}, \mathrm{CuSO}_{4}, \mathrm{THF} ; 2 . \mathrm{H}_{2} \mathrm{O}$. & 7vy & $0 \%$ & n.d. \\
\hline $6 w$ & (f) 1. $\mathrm{NaBH}_{4}, \mathrm{CuSO}_{4}, \mathrm{THF} ; 2 . \mathrm{H}_{2} \mathrm{O}$. & $7 w y$ & $0 \%$ & n.d. \\
\hline $5 v$ & $\begin{array}{l}\text { (g) 1. (trimethylsilyl)ethynyllithium, toluene, }-78^{\circ} \mathrm{C}, 3 \mathrm{~h} ; 2 . \mathrm{PPh}_{3} \\
\text { (4 equiv), THF, }-78^{\circ} \mathrm{C} ; 3 . \mathrm{H}_{2} \mathrm{O}, \mathrm{rt}, 2 \mathrm{~h} \text {. }\end{array}$ & $7 v y$ & $68 \%$ & $91: 9$ \\
\hline $5 w$ & $\begin{array}{l}\text { (g) 1. (trimethylsilyl)ethynyllithium, toluene, }-78^{\circ} \mathrm{C}, 3 \mathrm{~h} ; 2 . \mathrm{PPh}_{3} \\
\text { (4 equiv), THF, }-78^{\circ} \mathrm{C} ; 3 . \mathrm{H}_{2} \mathrm{O}, \mathrm{rt}, 2 \mathrm{~h} \text {. }\end{array}$ & 7 wy & $86 \%$ & $80: 20$ \\
\hline $7 v y$ & $\begin{array}{l}\text { (h) 1. } \mathrm{Boc}_{2} \mathrm{O} \text { ( } 2 \text { equiv), } \mathrm{THF} / \mathrm{H}_{2} \mathrm{O}(1: 1), \mathrm{NaHCO}_{3} \text { ( } 3 \text { equiv); } \\
\text { 2. imidazole, } 4 \text { h. }\end{array}$ & $7 v z$ & $45 \%$ & $91: 9$ \\
\hline $7 w y$ & $\begin{array}{l}\text { (h) 1. } \mathrm{Boc}_{2} \mathrm{O} \text { ( } 2 \text { equiv), } \mathrm{THF} / \mathrm{H}_{2} \mathrm{O}(1: 1), \mathrm{NaHCO}_{3} \text { ( } 3 \text { equiv); } \\
\text { 2. imidazole, } 4 \text { h. }\end{array}$ & $7 w z$ & $63 \%$ & $90: 10$ \\
\hline 7 wy & (i) BocHN-C(=NBoc)SMe (1 equiv), DCM, rt, $3 \mathrm{~d}$. & $7 x$ & $79 \%$ & $93: 7$ \\
\hline
\end{tabular}

the iminophosphorane, formed by the reaction of $\mathrm{PPh}_{3}$ with azide $6 \mathbf{w y}$, coordinates to the silyl group. This intramolecular coordination facilitates the fast hydrolytic cleavage of the silyl group during aqueous work-up. This $\mathrm{PPh}_{3}$-induced TMS cleavage could also be successfully applied in the synthesis of the lysine analogous propargylamine $7 \mathbf{v y}$ from $\mathbf{5 v}$ but could never be reproduced in the formation of other propargylamines, like the tert-butyl-substituted compound $\mathbf{7 e}$, under identical reaction conditions. The amine groups of $7 \mathbf{w y}$ and $7 \mathbf{v y}$ were protected with a Boc group to give propargylamines $\mathbf{7 w z}$ and $7 \mathbf{v z}$.

\section{Conclusion}

Ellman's chiral sulfinamide has been successfully used for the asymmetric synthesis of enantiomerically pure propargylamines. An array of 24 diastereomerically pure $N$-sulfinyl propargylamines has been prepared, bearing side chains in $\alpha$-position, which are analogous or similar to amino acid side 
chains. In general, various aldehydes are condensed with Ellman's chiral sulfinamide. Diastereoselective re-face addition of (trimethylsilyl)ethynyllithium to the $(S)$-configured sulfinimines 5 gives the corresponding $N$-sulfinyl propargylamines 6. Cleavage of the TMS group with TBAF or KF $\times 18$-crown- 6 provides $N$-sulfinyl propargylamines 7 with a terminal alkyne.

Propargylamines with aliphatic side chains were obtained in good yields, depending on the size of the $\mathrm{C}^{\alpha}$ substituent. Various polar and basic substituents in the side chain can be introduced using masked or protected functionalities. Side chains with amino groups were introduced masked as azide. For this purpose, the unprecedented intramolecular Huisgen reaction has to be suppressed. Electron-withdrawing substituents in the $C^{\beta}$-position could not be used by this approach. Electronwithdrawing substituents in the $\mathrm{C}^{\alpha}$-position induced an irreversible alkyne-allene- $\alpha, \beta$-unsaturated imine rearrangement under mild basic conditions, which makes an alkaline racemization of propargylamines improbable. Altogether, a large set of propargylamines with various amino acid similar substituents are available for application in peptidomimetics and some knowledge on the reactivity of propargylamines has been contributed.

\section{Supporting Information}

\section{Supporting Information File 1}

Details about the experiments, methods and materials, the

$\mathrm{X}$-ray crystal structures and NMR spectra.

[http://www.beilstein-journals.org/bjoc/content/ supplementary/1860-5397-13-240-S1.pdf]

\section{Acknowledgements}

The authors gratefully acknowledge Deutsche Forschungsgemeinschaft for financial support of the project (SE 609/10-1).

\section{ORCID ${ }^{\circledR}$ iDs}

Matthias Wünsch - https://orcid.org/0000-0002-3244-8374 David Schröder - https://orcid.org/0000-0002-7249-4156 Nils Janson - https://orcid.org/0000-0002-9681-5698 Jasmin Simon - https://orcid.org/0000-0002-8309-2267 Shari Heidemeyer - https://orcid.org/0000-0002-9254-7796 Alessa Hinzmann - https://orcid.org/0000-0002-1893-7892 Hans-Georg Stammler - https://orcid.org/0000-0002-0918-7057 Norbert Sewald - https://orcid.org/0000-0002-0309-2655

\section{References}

1. Patterson, A. W.; Ellman, J. A. J. Org. Chem. 2006, 71, 7110-7112. doi:10.1021/jo061160h
2. Verdoes, M.; Edgington, L. E.; Scheeren, F. A.; Leyva, M.; Blum, G.; Weiskopf, K.; Bachmann, M. H.; Ellman, J. A.; Bogyo, M. Chem. Biol. 2012, 19, 619-628. doi:10.1016/j.chembiol.2012.03.012

3. Patterson, A. W.; Wood, W. J. L.; Hornsby, M.; Lesley, S.; Spraggon, G.; Ellman, J. A. J. Med. Chem. 2006, 49, 6298-6307. doi:10.1021/jm060701s

4. Wood, W. J. L.; Patterson, A. W.; Tsuruoka, H.; Jain, R. K.; Ellman, J. A. J. Am. Chem. Soc. 2005, 127, 15521-15527. doi:10.1021/ja0547230

5. Inagaki, H.; Tsuruoka, H.; Hornsby, M.; Lesley, S. A.; Spraggon, G.; Ellman, J. A. J. Med. Chem. 2007, 50, 2693-2699. doi:10.1021/jm070111+

6. Moss, N.; Xiong, Z.; Burke, M.; Cogan, D.; Gao, D. A.; Haverty, K.; Heim-Riether, A.; Hickey, E. R.; Nagaraja, R.; Netherton, M.; O'Shea, K.; Ramsden, P.; Schwartz, R.; Shih, D.-T.; Ward, Y.; Young, E.; Zhang, Q. Bioorg. Med. Chem. Lett. 2012, 22, 7189-7193. doi:10.1016/j.bmcl.2012.09.054

7. Xu, H.-C.; Chowdhury, S.; Ellman, J. A. Nat. Protoc. 2013, 8, 2271-2280. doi:10.1038/nprot.2013.134

8. Brak, K.; Doyle, P. S.; McKerrow, J. H.; Ellman, J. A. J. Am. Chem. Soc. 2008, 130, 6404-6410. doi:10.1021/ja710254m

9. Brak, K.; Kerr, I. D.; Barrett, K. T.; Fuchi, N.; Debnath, M.; Ang, K.; Engel, J. C.; McKerrow, J. H.; Doyle, P. S.; Brinen, L. S.; Ellman, J. A. J. Med. Chem. 2010, 53, 1763-1773. doi:10.1021/jm901633v

10. Leyva, M. J.; DeGiacomo, F.; Kaltenbach, L. S.; Holcomb, J.; Zhang, N.; Gafni, J.; Park, H.; Lo, D. C.; Salvesen, G. S.; Ellerby, L. M.; Ellman, J. A. Chem. Biol. 2010, 17, 1189-1200. doi:10.1016/j.chembiol.2010.08.014

11. Deu, E.; Leyva, M. J.; Albrow, V. E.; Rice, M. J.; Ellman, J. A.; Bogyo, M. Chem. Biol. 2010, 17, 808-819. doi:10.1016/j.chembiol.2010.06.007

12. Jordan, S.; Starks, S. A.; Whatley, M. F.; Turlington, M. Org. Lett. 2015, 17, 4842-4845. doi:10.1021/acs.orglett.5b02408

13. Chen, B.-L.; Wang, B.; Lin, G.-Q. J. Org. Chem. 2010, 75, 941-944. doi:10.1021/j0902424m

14. Bauer, R. A.; DiBlasi, C. M.; Tan, D. S. Org. Lett. 2010, 12 , 2084-2087. doi:10.1021/ol100574y

15. Lee, S. I.; Park, S. Y.; Park, J. H.; Jung, I. G.; Choi, S. Y.; Chung, Y. K.; Lee, B. Y. J. Org. Chem. 2006, 71, 91-96. doi:10.1021/jo051685u

16. Ye, L.; He, W.; Zhang, L. Angew. Chem., Int. Ed. 2011, 50, 3236-3239. doi:10.1002/anie.201007624

17. Wünsch, M.; Senger, J.; Schultheisz, P.; Schwarzbich, S.; Michalek, C.; Klaß, M.; Goskowitz, S.; Borchert, P.; Jung, M.; Sewald, N. ChemMedChem, in press.

18. Nahrwold, M.; Bogner, T.; Eissler, S.; Verma, S.; Sewald, N. Org. Lett. 2010, 12, 1064-1067. doi:10.1021/ol1000473

19. Angelo, N. G.; Arora, P. S. J. Am. Chem. Soc. 2005, 127, 17134-17135. doi:10.1021/ja056406z

20. Johansson, J. R.; Hermansson, E.; Nordén, B.; Kann, N.; Beke-Somfai, T. Eur. J. Org. Chem. 2014, 2703-2713. doi:10.1002/ejoc.201400018

21. Kracker, O.; Góra, J.; Krzciuk-Gula, J.; Marion, A.; Neumann, B.; Stammler, H.-G.; Nieß, A.; Antes, I.; Latajka, R.; Sewald, N. Chem. - Eur. J. submitted.

22. Ko, E.; Liu, J.; Perez, L. M.; Lu, G.; Schaefer, A.; Burgess, K. J. Am. Chem. Soc. 2011, 133, 462-477. doi:10.1021/ja1071916

23. Temperini, A.; Capperucci, A.; Degl'Innocenti, A.; Terlizzi, R.; Tiecco, M. Tetrahedron Lett. 2010, 51, 4121-4124. doi:10.1016/j.tetlet.2010.05.143 
24. Weix, D. J.; Ellman, J. A. Org. Synth. 2005, 82, 157-165. doi:10.1002/0471264229.os082.24

25. Aggarwal, V. K.; Barbero, N.; McGarrigle, E. M.; Mickle, G.; Navas, R.; Suárez, J. R.; Unthank, M. G.; Yar, M. Tetrahedron Lett. 2009, 50, 3482-3484. doi:10.1016/j.tetlet.2009.03.020

26. Ellman, J. A.; Owens, T. D.; Tang, T. P. Acc. Chem. Res. 2002, 35, 984-995. doi:10.1021/ar020066u

27. Wakayama, M.; Ellman, J. A. J. Org. Chem. 2009, 74, 2646-2650. doi:10.1021/jo9001883

28. Arava, V. R.; Gorentla, L.; Dubey, P. K. Beilstein J. Org. Chem. 2011, 7, 9-12. doi:10.3762/bjoc.7.2

29. Huang, Z.; Zhang, M.; Wang, Y.; Qin, Y. Synlett 2005, 1334-1336. doi:10.1055/s-2005-865234

30. Higashibayashi, S.; Tohmiya, H.; Mori, T.; Hashimoto, K.; Nakata, M. Synlett 2004, 457-460. doi:10.1055/s-2004-815409

31. Liu, G.; Cogan, D. A.; Owens, T. D.; Tang, T. P.; Ellman, J. A. J. Org. Chem. 1999, 64, 1278-1284. doi:10.1021/jo982059i

32. Datta, G. K.; Ellman, J. A. J. Org. Chem. 2010, 75, 6283-6285. doi:10.1021/jo1011625

33. Collados, J. F.; Toledano, E.; Guijarro, D.; Yus, M. J. Org. Chem. 2012, 77, 5744-5750. doi:10.1021/jo300919x

34. Liu, G.; Cogan, D. A.; Ellman, J. A. J. Am. Chem. Soc. 1997, 119, 9913-9914. doi:10.1021/ja972012z

35. Foti, M. C.; Johnson, E. R.; Vinqvist, M. R.; Wright, J. S.; Barclay, L. R. C.; Ingold, K. U. J. Org. Chem. 2002, 67, 5190-5196. doi:10.1021/jo020184v

36. Peltier, H. M.; McMahon, J. P.; Patterson, A. W.; Ellman, J. A. J. Am. Chem. Soc. 2006, 128, 16018-16019. doi:10.1021/ja067177z

37. Patterson, A. W.; Peltier, H. M.; Sasse, F.; Ellman, J. A. Chem. - Eur. J. 2007, 13, 9534-9541. doi:10.1002/chem.200701057

38. Patterson, A. W.; Peltier, H. M.; Ellman, J. A. J. Org. Chem. 2008, 73, 4362-4369. doi:10.1021/j0800384x

39. Jung, H. H.; Floreancig, P. E. J. Org. Chem. 2007, 72, 7359-7366. doi:10.1021/jo071225w

40. González-Gómez, J. C.; Foubelo, F.; Yus, M. Synthesis 2009, 12, 2083-2088. doi:10.1055/s-0029-1216821

41. Robak, M. T.; Herbage, M. A.; Ellman, J. A. Chem. Rev. 2010, 110, 3600-3740. doi:10.1021/cr900382t

42. Chuang, C. P.; Gallucci, J. C.; Hart, D. J. J. Org. Chem. 1988, 53, 3210-3218. doi:10.1021/jo00249a014

43. Yang, X.; Nath, D.; Fleming, F. F. Org. Lett. 2015, 17, 4906-4909. doi:10.1021/acs.orglett.5b02481

44. Mancuso, A. J.; Huang, S.-L.; Swern, D. J. Org. Chem. 1978, 43, 2480-2482. doi:10.1021/jo00406a041

45. Cogan, D. A.; Liu, G.; Ellman, J. Tetrahedron 1999, 55, 8883-8904. doi:10.1016/S0040-4020(99)00451-2

46. Guijarro, D.; Pablo, Ó.; Yus, M. Tetrahedron Lett. 2009, 50, 5386-5388. doi:10.1016/j.tetlet.2009.07.044

47. Verrier, C.; Carret, S.; Poisson, J.-F. Org. Biomol. Chem. 2014, 12, 1875-1878. doi:10.1039/c3ob42352b

48. Turcaud, S.; Berhal, F.; Royer, J. J. Org. Chem. 2007, 72, 7893-7897. doi:10.1021/jo071139w

49. Carreira, E. M.; Du Bois, J. J. Am. Chem. Soc. 1995, 117, 8106-8125. doi:10.1021/ja00136a008

50. Nishikawa, T.; Ino, A.; Isobe, M. Tetrahedron 1994, 50, 1449-1468. doi:10.1016/S0040-4020(01)80629-3

51. Ferreira, F.; Audouin, M.; Chemla, F. Chem. - Eur. J. 2005, 11, 5269-5278. doi:10.1002/chem.200500268

52. Feuvrie, C.; Blanchet, J.; Bonin, M.; Micouin, L. Org. Lett. 2004, 6, 2333-2336. doi:10.1021/ol049346v
53. Levin, V. V.; Dilman, A. D.; Belyakov, P. A.; Struchkova, M. I.; Tartakovsky, V. A. Eur. J. Org. Chem. 2008, 5226-5230. doi:10.1002/ejoc.200800820

54. Moura-Letts, G.; DiBlasi, C. M.; Bauer, R. A.; Tan, D. S. Proc. Natl. Acad. Sci. U. S. A. 2011, 108, 6745-6750. doi:10.1073/pnas.1015268108

55. Ding, C.-H.; Chen, D.-D.; Luo, Z.-B.; Dai, L.-X.; Hou, X.-L. Synlett 2006, 1272-1274. doi:10.1055/s-2006-939076

56. Alzeer, J.; Vasella, A. Helv. Chim. Acta 1995, 78, 177-193. doi:10.1002/hlca.19950780117

57. Ernst, A.; Gobbi, L.; Vasella, A. Tetrahedron Lett. 1996, 37, 7959-7962. doi:10.1016/0040-4039(96)01838-2

58. Dierks, T.; Lecca, M. R.; Schmidt, B.; von Figura, K. FEBS Lett. 1998, 423, 61-65. doi:10.1016/S0014-5793(98)00065-9

59. Rabuka, D.; Rush, J. S.; deHart, G. W.; Wu, P.; Bertozzi, C. R. Nat. Protoc. 2012, 7, 1052-1067. doi:10.1038/nprot.2012.045

60. Brewer, G. A., Jr.; Johnson, M. J. Appl. Microbiol. 1953, 1, 163-166.

61. Weigel, L. F.; Nitsche, C.; Graf, D.; Bartenschlager, R.; Klein, C. D. J. Med. Chem. 2015, 58, 7719-7733. doi:10.1021/acs.jmedchem.5b00612

62. Pollegioni, L.; Harris, C. M.; Molla, G.; Pilone, M. S.; Ghisla, S. FEBS Lett. 2001, 507, 323-326. doi:10.1016/S0014-5793(01)02983-0

63. Asimakopoulou, A.; Panopoulos, P.; Chasapis, C. T.; Coletta, C.; Zhou, Z.; Cirino, G.; Giannis, A.; Szabo, C.; Spyroulias, G. A.; Papapetropoulos, A. Br. J. Pharmacol. 2013, 169, 922-932. doi:10.1111/bph.12171

64. Shu, M.; Yu, R.; Zhang, Y.; Wang, J.; Yang, L.; Wang, L.; Lin, Z. Med. Chem. (Sharjah, United Arab Emirates) 2013, 9, 32-44. doi:10.2174/157340613804488350

65. Shah, P.; Westwell, A. D. J. Enzyme Inhib. Med. Chem. 2007, 22, 527-540. doi:10.1080/14756360701425014

66. Gillis, E. P.; Eastman, K. J.; Hill, M. D.; Donnelly, D. J.; Meanwell, N. A. J. Med. Chem. 2015, 58, 8315-8359. doi:10.1021/acs.jmedchem.5b00258

67. De Clercq, E. Med. Res. Rev. 2009, 29, 611-645. doi:10.1002/med.20153

68. Prober, C. G. Adv. Exp. Med. Biol. 2004, 549, 9-12. doi:10.1007/978-1-4419-8993-2_3

69. Heidelberger, C. Ann. N. Y. Acad. Sci. 1975, 255, 317-325. doi:10.1111/j.1749-6632.1975.tb29239.x

70. Carmine, A. A.; Brogden, R. N.; Heel, R. C.; Speight, T. M.; Avery, G. S. Drugs 1982, 23, 329-353. doi:10.2165/00003495-198223050-00001

71. Corbett, J. W.; Ko, S. S.; Rodgers, J. D.; Gearhart, L. A.; Magnus, N. A.; Bacheler, L. T.; Diamond, S.; Jeffrey, S.; Klabe, R. M.; Cordova, B. C.; Garber, S.; Logue, K.; Trainor, G. L.; Anderson, P. S.; Erickson-Viitanen, S. K. J. Med. Chem. 2000, 43, 2019-2030. doi:10.1021/jm990580e

72. Maggiolo, F. J. Antimicrob. Chemother. 2009, 64, 910-928. doi:10.1093/jac/dkp334

73. King, J.; Aberg, J. A. AIDS (London, U. K.) 2008, 22, 1709-1717. doi:10.1097/QAD.0b013e32830163ad

74. Cipriani, A.; Barbui, C.; Brambilla, P.; Furukawa, T. A.; Hotopf, M.; Geddes, J. R. J. Clin. Psychiatry 2006, 67, 850-864. doi:10.4088/JCP.v67n0601

75. Owen, R. T. Drugs Today 2006, 42, 185-192. doi:10.1358/dot.2006.42.3.953589

76. Kim, S. S. Ann. Pharmacother. 2003, 37, 890-892. doi:10.1345/aph.1C362 
77. Foster, R. S.; Jakobi, H.; Harrity, J. P. A. Org. Lett. 2012, 14, 4858-4861. doi:10.1021/ol3021918

78. Corbett, J. W.; Ko, S. S.; Rodgers, J. D.; Jeffrey, S.; Bacheler, L. T.; Klabe, R. M.; Diamond, S.; Lai, C. M.; Rabel, S. R.; Saye, J. A.; Adams, S. P.; Trainor, G. L.; Anderson, P. S.; Erickson-Viitanen, S. K. Antimicrob. Agents Chemother. 1999, 43, 2893-2897.

79. Jiang, B.; Si, Y.-G. Angew. Chem., Int. Ed. 2004, 43, 216-218. doi:10.1002/anie.200352301

80. Magnus, N. A.; Confalone, P. N.; Storace, L. Tetrahedron Lett. 2000, 41, 3015-3019. doi:10.1016/S0040-4039(00)00331-2

81. King, R. W.; Klabe, R. M.; Reid, C. D.; Erickson-Viitanen, S. K. Antimicrob. Agents Chemother. 2002, 46, 1640-1646. doi:10.1128/AAC.46.6.1640-1646.2002

82. Corbett, J. W. Curr. Med. Chem. - Anti-Infect. Agents 2002, 1, 119-140. doi:10.2174/1568012023354938

83. Kauffman, G. S.; Harris, G. D.; Dorow, R. L.; Stone, B. R. P.; Parsons, R. L., Jr.; Pesti, J. A.; Magnus, N. A.; Fortunak, J. M.; Confalone, P. N.; Nugent, W. A. Org. Lett. 2000, 2, 3119-3121. doi:10.1021/ol006321x

84. Prakash, G. K. S.; Mandal, M.; Olah, G. A. Angew. Chem., Int. Ed. 2001, 40, 589-590. doi:10.1002/1521-3773(20010202)40:3<589::AID-ANIE589>3.0.CO;29

85. Prakash, G. K. S.; Mandal, M.; Olah, G. A. Org. Lett. 2001, 3, 2847-2850. doi:10.1021/ol010134x

86. Magueur, G.; Crousse, B.; Bonnet-Delpon, D. Tetrahedron Lett. 2005, 46, 2219-2221. doi:10.1016/j.tetlet.2005.02.030

87. Magueur, G.; Crousse, B.; Bonnet-Delpon, D. Eur. J. Org. Chem. 2008, 1527-1534. doi:10.1002/ejoc.200701090

88. Bégué, J.-P.; Bonnet-Delpon, D.; Crousse, B.; Legros, J. Chem. Soc. Rev. 2005, 34, 562-572. doi:10.1039/b401707m

89. Bravo, P.; Crucianelli, M.; Vergani, B.; Zanda, M. Tetrahedron Lett. 1998, 39, 7771-7774. doi:10.1016/S0040-4039(98)01698-0

90. Asensio, A.; Bravo, P.; Crucianelli, M.; Farina, A.; Fustero, S.; Soler, J. G.; Meille, S. V.; Panzeri, W.; Viani, F.; Volonterio, A.; Zanda, M. Eur. J. Org. Chem. 2001, 1449-1458. doi:10.1002/1099-0690(200104)2001:8<1449::AID-EJOC1449>3.0.C O;2-2

91. Crucianelli, M.; De Angelis, F.; Lazzaro, F.; Malpezzi, L.; Volonterio, A.; Zanda, M. J. Fluorine Chem. 2004, 125, 573-577. doi:10.1016/j.jluchem.2003.11.034

92. Lazzaro, F.; Crucianelli, M.; De Angelis, F.; Frigerio, M.; Malpezzi, L.; Volonterio, A.; Zanda, M. Tetrahedron: Asymmetry 2004, 15 , 889-893. doi:10.1016/j.tetasy.2004.01.013

93. Greier, G. Synthesis of Novel Trifluormethyl-Substituted Thienothiazines; Vienna University of Technology, 1983.

94. Truong, V. L.; Ménard, M. S.; Dion, I. Org. Lett. 2007, 9, 683-685. doi:10.1021/ol063001q

95. Xiao, H.; Huang, Y.; Qing, F.-L. Tetrahedron: Asymmetry 2010, 21 , 2949-2955. doi:10.1016/j.tetasy.2010.11.028

96. Kuduk, S. D.; Di Marco, C. N.; Pitzenberger, S. M.; Tsou, N. Tetrahedron Lett. 2006, 47, 2377-2381. doi:10.1016/j.tetlet.2006.01.154

97. Vartanyan, S. A.; Badanyan, S. O. Russ. Chem. Rev. 1967, 36, 670. doi:10.1070/RC1967v036n09ABEH001681

98. Srinivasan, R.; Uttamchandani, M.; Yao, S. Q. Org. Lett. 2006, 8, 713-716. doi:10.1021/ol052895w

99. Chen, S.; Zhao, X.; Chen, J.; Chen, J.; Kuznetsova, L.; Wong, S. S.; Ojima, I. Bioconjugate Chem. 2010, 21, 979-987. doi:10.1021/bc9005656
100.Corrie, J. E. T.; Hlubucek, J. R.; Lowe, G. J. Chem. Soc., Perkin Trans. 1 1977, 1421-1425. doi:10.1039/p19770001421

101. Koreeda, M.; Yang, W. Synlett 1994, 3, 201-203. doi:10.1055/s-1994-22794

102.Bitonti, A. J.; Casara, P. J.; McCann, P. P.; Bey, P. Biochem. J. 1987, 242, 69-74. doi:10.1042/bj2420069

103. Metcalf, B. W.; Jung, M. a-Acetylenic Derivatives of Amines. U.S. Patent US4139563 A, Feb 13, 1979.

104. Metcalf, B. W.; Jung, M. a-Acetylenic Derivatives of a-Amino Acids. U.S. Patent US4182891 A, Jan 8, 1980.

105.Amantini, D.; Fringuelli, F.; Piermatti, O.; Pizzo, F.; Zunino, E.; Vaccaro, L. J. Org. Chem. 2005, 70, 6526-6529. doi:10.1021/jo0507845

106. Huisgen, R. Angew. Chem., Int. Ed. Engl. 1963, 2, 565-598. doi:10.1002/anie.196305651

107.Panday, N.; Meyyappan, M.; Vasella, A. Helv. Chim. Acta 2000, 83, 513-538. doi:10.1002/(SICI)1522-2675(20000315)83:3<513::AID-HLCA513>3.0 .CO;2-1

108.Panday, N.; Vasella, A. Helv. Chim. Acta 2000, 83, 1205-1208. doi:10.1002/1522-2675(20000607)83:6<1205::AID-HLCA1205>3.0.C O;2-L

\section{License and Terms}

This is an Open Access article under the terms of the Creative Commons Attribution License (http://creativecommons.org/licenses/by/4.0), which permits unrestricted use, distribution, and reproduction in any medium, provided the original work is properly cited.

The license is subject to the Beilstein Journal of Organic Chemistry terms and conditions:

(http://www.beilstein-journals.org/bjoc)

The definitive version of this article is the electronic one which can be found at: doi: $10.3762 /$ bjoc. 13.240 